\title{
Çağdaş Sanat ve Kimlik: Grayson Perry Eserleri Üzerinden Bir İnceleme
}

\author{
ÇİĞDEM SAÇ KAVRAYAN* \\ cigdemsac@gmail.com \\ ORCID-ID: 0000-0001-9570-1712
}

\begin{abstract}
Öz: 1960’h yillardan günümüze kadar süregelen çağdaş sanat, üretim yöntemleri açısından sanatçıların tamamen farklılaştı̆̆ı bir akımı oluşturmaktadır. Çağdaş sanat feminizm, küreselleşme, çevre, teknoloji, kimlik, sınıf gibi kavramlarla ilgilenmektedir. Çağdaş sanatçıların disiplinler arası çalışmalar, çeşitli materyaller, değisşik teknikler ile farklılaştıkları görülmektedir. Çağdaş sanatçılar geniş ilgi alanları içinde farklı cinsel kimlikler ve alt kimlikleri de tartışmaktadır. Grayson Perry, Britanya’nın en tanınmış çağdaş sanatçıları arasında yer almaktadır. Günümüz çağdaş sanatının en sıra dışı ve ikonik isimlerinden biri olarak nitelendirilmektedir. Grayson Perry, toplumdaki sinıf farklarını, modern sıkıntıları ve kimlik meselelerini ele almaktadır. Seramik, baskı ve heykel çalışan Grayson Perry, eserlerinde ipek, pamuklu kumaş, pirinç, fotoğraf gibi çeşitli malzemeler kullanmaktadır. Bu çalışmada Grayson Perry'nin kimlik kavramını eserlerinde ele alışı incelenmektedir.
\end{abstract}

Anahtar kelimeler: Sanat, Çă̆daş sanat, Grayson Perry, Kimlik, Sinıf.

\section{Giriş̧}

Genellikle geç 20. yüzyıl veya İkinci Dünya Savaşı sonrası sanatını ve yoğunluklu olarak 1970 sonrası sanatı tanımlamak için kullanılan çağdaş sanat terimi ${ }^{1}$ hem biçim hem de konu açısından çoğunlukla alışılmadık bulunmaktadır. Çağdaş sanat, modern sanatın aksine üretim yöntemlerine ve akımlara göre incelenmesi güç; çevre ve toplum bilincinin ağır bastığı; ağırlıklı olarak feminizm, küreselleşme, çevre, biyo-mühendislik, teknoloji-insan ilişkisi, çok kültürlülük, sınıf ve kimlik gibi konularla ilgilenmektedir.

Bireyin, toplumsal kategoriler içerisinde adlandırılma süreci olarak tanımlanan kimliğin ifade araçlarından biri sanattır. Çağdaş sanat, devlet, toplum, ekonomik sistem ve tüm bu faktörlerin oluşturduğu psikolojik boyutlar üzerinden incelediği kimlik oluşumuna, cinsel kimlikler ve alt kimlikler gibi daha önce yeterince gündeme geti-

\footnotetext{
* Yüksek Lisans Öğrencisi, Kocaeli Üniversitesi, Sosyal Bilimler Enstitüsü, Resim Anasanat Dalı.

1 Bengisu Bayrak, "Çağdaş Sanat Pazarında Bir Marka Olmak: Bir Vaka İncelemesi Olarak Damien Hirst", Nevşehir Üniversitesi Sosyal Bilimler Dergisi, 2 (2012), s.242.
} 
rilmemiş alanlardan da bakmaktadır. ${ }^{2}$

Modern sanatın veya modernist dönemin bittiği kabul edilen yıllardan günümüze kadar süregelen ve bir akım veya üslup benzeri birleştirici özellikleri olmadığından genel bir deyişle 'çağdaş' olarak adlandırılan sanat biçiminin birçok temsilcisi bulunmaktadır.

Çağdaş sanat temsilcileri arasında yer alan ve 2003 yılında Birleşik Krallık’ta çağdaş sanat alanındaki en prestijli ödül olan Turner Ödülü (Turner Prize) alan Grayson Perry, Britanya’nın en tanınmış çağdaş sanatçıları arasında yer almaktadır. Günümüz çağdaş sanatının en sıra dışı ve ikonik isimlerinden biri olarak nitelendirilen Grayson Perry, toplumdaki sınıf farklarını, modern sıkıntıları ve kimlik meselelerini ele almaktadir.

Bu çalışmada henüz akademik bir çalışma kapsamında ele alınmamış ancak çağdaş sanatın günümüz temsilcilerinden biri olan, seramik, baskı ve heykel çalışan Grayson Perry’nin çağdaş sanatın önemli konularından biri olan kimlik meselesini sanatsal açıdan ele alışı incelenecektir.

\section{Kavramsal Boyutuyla Çağdaş Sanat ve Çağdaş Sanatın Bakış Açısı}

Sanat, bir arama ve sorgulama biçimi ya da bir dil olarak tanımlanırsa bu dilin insanoğluyla paralel olarak değiştiğini söylemek mümkündür. İnsan ve sanat ilişkisi, sanayi devrimiyle geri dönülmez bir yola girmiştir. Böylece çağ yakalama ve çağdaş olma, sanatın da sorunu olmuştur. Çağdaş dünya sanatını kavrayabilmek için "sanat", "çağdaş" ve "çağdaş sanat" terimlerinin anlaşılması önemlidir. Zira bir kavram, salt sözcük anlamından çok daha fazlasını içermektedir ve zamanla ona pek çok anlam yüklenmektedir. ${ }^{3}$

Türk Dil Kurumu’na göre çağdaş, "Bulunulan çağın anlayışına, şartlarına uygun olan, çağcll, uygarca, modern, asri”" anlamına gelmektedir. Çağdaş sanat ise, kavramsal olarak tanımlanması en zor olan sanat anlayışlarından birini oluşturmaktadır. Tarihsizliği ifade eden "çağdaş sanat" lardır tartıştığı ifade edilmektedir. Ancak literatürde ağırlıklı olarak modern sanatın sonuna işaret eden bir kavram olduğu ve bu kavramın, şimdiki zamanda olup biten bir hadise yerine, bir döneme karşılık geldiği ve bu dönemin de küresellik olduğu konularında bir uzlaşının olduğu görülmektedir. ${ }^{5}$ Öte yandan çağdaş sanatın böyle tartışmalı hale gelmesinde temel belirleyicinin, çağdaş sanatın çeşitlilik gösteren biçimi ve geleneksel olarak sanat denilen alanın ilerisinde seyredişi olduğu da ifade edilmektedir.

Çağdaş sanat, toplumun özellikle 1950’lerden sonra ilgilendiği "küreselleşme, feminizm, teknoloji, biyo genetik, insanın modern çağdaki sosyokültürel değişimi” gibi

2 Aytül Papila, "Kimliğin Anlatım Aracı Olarak Sanat”, Beykent Üniversitesi Sosyal Bilimler Dergisi, 1 (2007), s.187.

3 İsmail Şamil Yaman vd., Çağdaş Dünya Sanatı, Ankara: Saray Matbaacılık, 2013, s.10.

4 “Çağdaş", Türk Dil Kurumu, Türkçe Sözlük, Ankara, 2006, s.268.

5 Ali Artun ve Nursu Örge, Çağdaş Sanat Nedir?, İstanbul: İletişim Yayınları, 2014. 
farklı konularla ilgilenmektedir. 1960'lardan itibaren şekillenmeye başlayan çağdaş sanat akımı, günümüzde birçok sanat tarihçisi tarafından "modern sanat olarak tabir edilen akımın sona ermesi olarak" kabul edilmektedir. Öte yandan modern sanat akımının tamamen zıttı olduğu belirtilen çağdaş sanat, üretim yöntemleri açısından da sanatçıların tamamen farklılaştığı bir akımı oluşturmaktadır.

Günümüzde de etkilerini sürdüren ve birçok sanatçı tarafından uygulanmakta olan çağdaş sanat, 1960'larda gelişimine başlayan ve 1970'lerden itibaren dünya genelinde sanattan mimariye birçok alanda etkilerini gösteren bir sanat akımıdır. Belirli çizgileri ve katı kuralları olmayan sanat anlayışını simgelediği için "çağdaş” olarak isimlendirilen bu anlayış, biçim ve konu açısından çoğunlukla alışılmadık olduğu için bu türdeki eserler zorlayıcı bulunmaktadır. ${ }^{6}$

Sanat dünyasında "çağdaş" sıfatı, postmodernizm tartışmalarıyla aynı süreçte yerini almıştır. 1980'lerle birlikte, çeşitli yayınlarda "modern” sanattan sonra "postmodern" ya da "çağdaş" sanattan söz edildiği görülmektedir. Bu durum, modern kavramının 1980 sonrası sanatını nitelemek için yetersiz kaldığını göstermektedir. Böylece bugünün sanatına "modern” denemeyeceği ancak ayrımı belirtmek gerektiği için "çağdaş" kavramının kullanımının uygun olduğu belirtilmektedir. ${ }^{7}$

Dolayısıyla çağdaş sanat akımı; modernizm döneminin sona ermesinin ardından gelişen postmodernizm akımlarını da kapsayan, bunun dışında diğer birçok anlayışı içinde barındıran ve "hala devam eden" bir süreci ifade etmektedir. Öte yandan günümüzde çağdaş sanat denildiğinde, çoğulcu, eklektik ve hatta multidisipliner bir yapıdan bahsedilmekte olduğu bilinmektedir. ${ }^{8}$

Çağdaş sanatı, tüm sanatsal ifade olanaklarını bünyesinde barındıran ve her türden üretime sanat olma meşruiyeti kazandıran bir bütün olarak tespit etmek ${ }^{9}$ mümkündür. Ayrıca çağdaş sanat içinde çağın koşullarına uymak ve bu koşulları yansıtıp geliştirmek endişesi de söz konusudur. Çağdaş sanat; dilini, varlığını, ortamını ve amacını sorgulayarak kendini sürekli geliştirmektedir. Bu gelişim, çeşitli düşünsel süreçleri gerektirmektedir. Çağdaş sanatın ayırıcı özelliği, sanatın boy atması, gelişmesiyle olan doğrudan ilişkisidir. ${ }^{10}$

Günümüz sanatı; tüm sanatsal söylemlerin, buna sanatın sonlandığı, resmin öldüğü söylemleri de dahil olmak üzere, ziyadesiyle çoğaldığ 1 ve tartışıldığ 1 yeni sanat kavrayışı olarak, bütün sınırların bulanıklaştığı ve birbirine karıştığı bir gerçekliğe sahiptir. ${ }^{11}$ Nitekim çağdaş sanat üzerine yazan Rajchman’a göre çağdaş sanat için temel kırılma 1980'li yıllarla birlikte yaşanmıştır. 1980'li yıllar ile birlikte neoliberal

6 Graham Whitham ve Grant Pooke, Çağdaş Sanatı Anlamak, çev. Tufan Göbekçin, İstanbul: Optimist Yayınları, 2010.

7 Mehmet Yılmaz, Modernizmden Postmodernizme Sanat, Ankara: Ütopya Yayınları,2006, s.28.

8 Orçun Çadırcı, “Çağdaş Sanat Sürecinde Resimsel Bir Dil Olarak Neo-Geo”, Gazi Üniversitesi Güzel Sanatlar Fakültesi Sanat ve Tasarım Dergisi, 5 (2010 Haziran), s.54.

9 Fredric Jameson, Jean-François Lyotard, Jürgen Habermas, Postmodernizm, haz. Necmi Zeka, çev., Gülengül Naliş, Dumrul Sabuncuoğlu, Deniz Erksan, İstanbul: Kıyı Yayınları, 1994, s. 43-51.

10 Yaman vd., Çağdaş Dünya Sanatı, s.10.

11 Çadırc1, “Çağdaş Sanat Sürecinde”, s.54. 
eksende gelişen günümüz çağdaş sanatının artık küresel sanatı oluşturduğunu ifade etmektedir. Ona göre neoliberal yeni düzende, çağdaş sanat Avrupa modernizminin hikaye ve kaygılarından kurtulmuş yeni bir sanat fikri olarak yükselmiştir. Görsel sanatlar, artık bir atölyede üretilmesi veya beyaz küp mekanında sergilenmesi şart olmayan, hatta geleneksel heykel ya da resim becerilerini bile gerektirmeyen, yeni, keşfedilmemiş bir alana adım atmaktadır. Böylece görsel sanatlar ve sanat kurumları, başka sanat türlerinde modernizmde tam karşılı̆̆ı olmayan yeni bir role sahip olmuştur. Rajchman’a göre 1980'li yılların küresel sanatında, sanatın yeniliği artık yeni bir takvimde işlemektedir. Buna göre bir zamanlar çağdaş olarak adlandırılan sanatlar, hem daha önceki "modernist" katmanlarla hem de yerel "geleneksel" katmanlarla içiçe geçmiş, karmakarışık bir durum içindeki katmanlardan sadece biri gibi görünmektedir. Bu durum artık tarihçilerin, sanat eleştirmenlerinin, müze küratörlerinin de bakış açılarının, tarzlarının değişmesine yol açmaktadır. ${ }^{12}$ Bu durum çağdaş sanat temsilcilerinin de disiplinlerarası yorumlar, çalışmalar yapması sürecini ifade etmektedir.

Çağdaş sanatçılar tüm disiplinleri kullanarak çoğulcu bir yaklaşımla metinler, sıra dışı ve eklektik görsel imgeler kullanırlar. Sanat nesneleri ve deneyimlerinde politik, kültürel, sosyal ve psikolojik düşünceleri yansıtırlar. Sanatçılar nesneleri yaratırken daha önceki tecrübelerinden, tarihten, görsel birikimlerinden ve çevreden referanslar alırlar. ${ }^{13}$

Çağdaş sanatın sorunsalları Modernizm’den sonra gelişme göstermiş, sanatçı odaklı ya da öznel deneyimlerin tartışıldığı bir platform belirginlik kazanmıştır. Sanatçıların 1960'lardan bu yana düşünce bazlı ürettikleri işler, toplumsal, kültürel, öznel, hayata dair kavramların ve değerlerin yeniden sorgulandığı, sanatçıların eserlerindeki boyasal resim geleneğine atıfta bulunarak, çoğunlukla özneyi sorgulayan yeni olasılık ve seçeneklerle çoğulcu bir yaklaşım sergiledikleri dikkat çekmektedir. Öyle ki sanatçılar salt boya ile üretilen işlerin yanı sıra, malzeme çeşitliliğiyle gerek plastik gerekse düşünsel anlamda tezatların deşifre edildiği yeni, deneysel nitelikli söylem ve arayışlarıyla adeta kimliksel bir çözümleme yoluna gitmişlerdir. Buna paralel olarak 1980'li yıllar radikal dönüşümlerin tanıklık ettiği bir dönemi yansıtmaktadır. Yeniyi arayan, farklı kültür ve değerleri aynı potada eriten çağdaş sanatçıların plastik ve düşünsel sentezlerde birincil amaçları kendilerini ifade etmeleri olmuştur. Bu perspektifle sanatçllar kimi zaman öznel ve yerel değerleri harmanlayarak kimi zaman da deneyimlerini korumak, aktarmak adına entelektüel ve estetik bir diyalektik kurmuşlardır. ${ }^{14}$

\section{Çağdaş Sanat Temsilcisi Olarak Grayson Perry ve Çalışmaları}

"Fikirlerin" tek talibi olarak kavramsal sanatı reddeden Grayson Perry, çağdaş sanatı kinayeli bir dille eleştirerek, çağdaş sanata savaş açan bir çağdaş sanat temsilcisidir.

12 John Rajchman, “Çağdaş: Yeni Bir Fikir mi?”, Çağdaş Sanat Nedir?, ed., Ali Artun, Nursu Örge, İstanbul: İletişim Yayınları, 2014, s.19-37.

13 Papila, "Kimliğin Anlatım Aracı", s.188.

14 Alpaslan Uçar, “Çağdaş Sanatta Kimlik Açılımı ve Yeni Önermeler”, Ege Eğitim Dergisi, 15/2 (2014), s.418-419. 
"İyi ve kötü sanat nedir ve önemli midir? Bir sanat eserinin değerli olduğuna, hangi sanat eserinin takdir edilmesi gerektiğine kim karar verir?” gibi sorular sormakta ve herkesin çağdaş sanattan zevk alıyormuş gibi yapma konusunda usta olduğunu ifade etmektedir. Bu ifadesini desteklemek amaciyla da bazı eserlerin, onu ortaya koyan sanatçı dışındaki kişiye anlam yüklemesi zor bir nesneden ibaret olduğunu belirtmektedir. Perry, bu düşünce ve duygularını illüstrasyonlarında sert ve kinayeli bir dille ortaya koymaktadır. Aslında Perry, çağdaş sanatın herkes tarafından anlaşılması gerektiğini düşünmekte ve bunu gerek sözleri gerekse çalışmalarında sanat camiasını sert şekilde eleştirerek sunmaktadır. ${ }^{15}$ Yavaş ve kademeli değişimleri seven, aşırılık ve devrimciliği sevmeyen Perry bu durumu eser sürecine de yansıtmakta ve "Yaratım sürecim yavaş, detaylı ve zahmetli, insanların eserlerimdeki işgücünü hissetmesini istiyorum.” şeklinde dile getirmektedir. ${ }^{16}$

Perry, içinde büyüdüğümüz sosyal sınıfı, estetik zevkimizi şekillendiren en güçlü unsur olarak görmektedir. Gündelik olanı, insanların hayatlarını yaşama biçimini, modern dertleri, din, sınıf ve kimlik meselelerini işleyen sanatçı, zevklerin toplumsal bağlama göre iyi veya kötü olarak tanımlandığını düşünmektedir. Çağdaş sanat formlarını çalışmalarında kullanarak, milliyetçilik, aile, din, cinsiyet gibi kavramları sorgulamaktadır. Bu sorgulayışta, kendisinin de ifade ettiği gibi içinde büyüdüğü sosyal sınıfın, ailenin ve tanıklıkların izini görmek mümkündür. ${ }^{17}$

Nitekim 1960'da İngiltere Essex'de doğan Perry, Thatcher döneminde büyümüş olması sebebiyle kitlesel işsizlik ve endüstriyel gelişmeler gibi sosyo-ekonomik birçok değişime şahit olmuştur. 1980'li yıllarda işçi sınıfının yoğun olduğu Essex’te kadınların sarı saç, yanık ten ve beyaz topuklu ayakkabılarla, erkeklerin ise hoş arabalar içinde gezdikleri bir yaşamı görmüş ve çalışmalarında bu tanıklıklarından da esinlenmiştir. ${ }^{18}$ Perry, eserlerinde espirili bir eleştiri dili kullanmakta ve işçi sınıfı ile dalga geçerken aslında kendi ile dalga geçmektedir.

Anne ve babası boşanmış bir ailenin çocuğu olan Perry, agresif bir adam olarak nitelendirdiği üvey babası ile anlaşamadığını ifade etmektedir. Klişelere karşı oldukça yoğun bir ilgisi olan sanatçı "hepimiz hayal dünyamızı kendimiz doğururuz" diyerek, çalışmalarında çok yer verdiği ayısı Alan Miesels’ı hayal dünyasının kahramanı, diktatör olarak tanımlamaktadır. Perry ve sanatı için önemli bir figür olan oyuncak ayıyı, tartışma yaratan "Vote Alan Measles for God" (Tanrı Olarak Alan Measles’a Oy Verin) ve "Wise Alan" (Bilge Alan) gibi eserleri başta olmak üzere birçok eserinin odak noktasında veya detaylarında dini bir figür, güçlü bir kişilik, bir kimlik temsili olarak kullandığı görülmektedir.

Perry, çocukken ilgi eksikliği içinde büyümüş ve özellikle "derin bir kadın ilgisi ihtiyacı” duyduğunu yaşamının farklı alanlarında ifade etmektedir. Bir kadın olma isteği

15 Grayson Perry, Playing to the Gallery, Penguin Books Ltd, 2014.

16 “Grayson Perry’den Küçük Farklılıklar”, Mimarizm, erişim 27 Kasım, 2017. http://www.mimarizm.com/ etkinlikler/sergiler/grayson-perry-den-kucuk-farkliliklar_121380.

17 "Grayson Perry: The Rise and fall of Default Man”, Newstatesman, erişim 1 Şubat, 2018, https://www. newstatesman.com/culture/2014/10/grayson-perry-rise-and-fall-default-man.

18 Jacky Klein, Grayson Perry, 2nd edition, London: Thames \& Hudson, 2009. 
taşımamasına ve hatta mutlu bir evliliği olmasına rağmen, kadınların aldığı ilgiyi deneyimlemek istemektedir. Bu sebeple kimi zaman kadın kıyafetleri giyerek, kendisiyle birlikte küçük bir kız çocuğundan genç bir kadına doğru evrilen Claire'in kılığında sergilerine, açılışlara gitmekte, televizyon ekranına Claire olarak çıkmaktadır. On iki yaşında ilk olarak kız kardeşlerinin bale giysileri ile kadın kıyafetleri giymeye başladığını belirten Perry’e bir kız arkadaşı giydiği kıyafetlere uygun bir isim olarak "Claire" adını vermiştir ${ }^{19}$ ve Claire, Perry’nin pek çok çalışmasında da karşımıza çıkmaktadır.

Her şeyi denemeye açık, eleştirilmekten, demode olmaktan korkmayan ve kadın k1yafeti giyme işini sanat olarak yapmayan sanatçı, kadın kılığına girmenin komik, absürd ve kabul görülmeyecek olabileceğini ancak bu dürtü ile yaşamanın komikliğine vurgu yapmaktadir.

Karısı psikoterapist olan sanatçı, çok sık depresyona girmektedir. Altı sene psikoterapi gören Perry, seanslarını "birisi zihinsel alet kutuma gelmiş ve düzenlemiş gibi istediklerimi daha rahat buluyorum” şeklinde tanımlayarak, eserlerine yansıtmıştır. Perry, terapilerinin ardından terapide konuşulan kavramlar üzerinden olmayan bir ülke, olmayan halklardan oluşan ama gerçek kavramların yer aldığı hayali haritalar yapmaktadır. "Map of an Englishman", psikoterapinin sonucunda bir otoportre gibi ortaya çıkan eserleri arasında yer almaktadır. Eser, insan beynine benzemektedir ve Perry eserine karısı ile birlikte kelimeleri dökmüştür. "Map of days" surlarla çevrili şehir eseri ise, surların içini kendi içimiz olarak temsil etmekte, dışarıdan içeriye girenleri ve içeriden dışarıya çıkanları yansıtmaktadır. Haritaları bir ucundan başlatıp sonuna kadar ilerleyerek tek bir seferde bitiren Perry, haritaları önceden planlamıyor ve sadece o seansta kullanılan kavramları aktarıyor. ${ }^{20}$

Gerek kullandığı malzemeler gerekse mekânsal uygulamalardaki farklılıkları ile çağdaş sanatın günümüz temsilcileri arasına giren Perry, eserlerinin özgünlügü ve çalışmalarının güzel sanatlar ile zanaat arasındaki ince çizgide duruşu ile de dikkat çekmektedir. Seramiğin, sanat dünyasında ikinci ve üçüncü sınıf bir malzeme olarak görüldüğü İngilterede, seramik malzemesine ilgi duymuştur. 17. yy İngiliz çömlekçiliği, Afgan duvar halıları, İslam çömlekçiliği, kitaplarda gördügü seramikler Perry için ilham kaynakları olmuştur.

Perry, çalışmalarında ipek, pamuklu kumaş, pirinç, fotoğraf gibi malzemeler kullanırken, minyatür bir portre, duvar dokuması, heykeller, halılar, çanaklar, vazolar gibi özgün eserlerle toplumdaki sınıf farklarını, modern sıkıntıları ve kimlik meselelerini ele almaktadır.

Perry, anlatacak hikâyeleri olan el yapımı nesnelerin süslemeci ve samimi niteliklerini savunmaktadır. Birçok çalışması ve sergisi bulunan sanatçının çalışmalarının ortak özelliği, "kimlik" konusudur. Özellikle kimliğini değiştiren veya kimliği değişen

19 Wendy Jones, Grayson Perry: Portrait of an Artists As A Young Girl, UK: Vintage Books, 2007.

20 “Grayson Perry Üzerine”, Kikasworld, erişim 28 Ocak, 2018. https://kikasworld.com/2015/06/18/graysonperry-uzerine. 
sıradan insanların ele alındığı çalışmalarda milliyetçilik, aile, cinsiyet gibi kavramlara meydan okumaktadır.

\section{Çağdaş Sanatta Kimlik ve Grayson Perry Eserlerinde Kimlik}

Kimlik, "Toplumsal bir varlık olarak insana özgü olan belirti, nitelik ve özelliklerle, birinin belirli bir kimse olmasını sağlayan şartların bütünü” olarak tanımlanmaktadır. ${ }^{21}$ Günümüz dünyasının en büyüleyici ve en ilgi çekici kavramlarından biri olarak nitelendirilen kimlik en geniş anlamıyla, bireyin tüm özelliklerini kapsamaktadır. Hem kişinin kendisini nasıl gördüğü, hem de toplum tarafından nasıl görüldüğü, kimlik kavramıyla ilgili konuları oluşturmaktadır. ${ }^{22}$ Toplumun sosyal sisteminin en temel ve en önemli kökenini oluşturan kimlik kavramı, yüzeysel olarak kısaca kişilerin ve çeşitli büyüklük ve nitelikteki toplumsal grupların "kimsiniz, kimlerdensiniz" sorusuna verdikleri cevaplardir. ${ }^{23}$

Tarihsel süreç içinde toplumsal yapılanmaların geçirdiği her evreye göre kimliğin de farklı oluşumlar gösterdiği görülmektedir. Toplumlar karmaşıklaştıkça ve değişip geliştikçe kimlik kavramını anlamlandırma parametreleri de değişmiştir. Örneğin geleneksel dönemde kimlik ait olunan aile, klan, soy gibi gruplarla özdeşleştirilmişken; modernizmle birlikte toplumsal yaşantının merkezine bireyin kendisi geçirilmiş ve modern toplumlarda kimlik çoklu ve hareketli bir yapıya bürünmüştür. Öte yandan toplumsal işbölümü ve rollerin arttığı modern toplumlarda bireyin kendisini 'öteki' üzerinden inşa ettiği söylenebilir. Ancak postmodern döneme gelindiğinde, onun şüpheci, eleştirel, olumsuz tavrı ile modern dönemin bütün değer ve düşünce sistemleri sorguya alınmıştır. postmodern dönem ötekinin reddine, farklılığın kendi kimliğimizin güvenliği adına değersizleştirilmiş bir ötekine indirgenmesine karşı çıkılan; söylemler, kültürler, mücadele ve sesler çokluğunun güvence altına alınmasının gerekliliğini vurgulayan bir dönem olarak belirir ve çoğulcu kimlik politikaları sunar. ${ }^{24}$

Görünüş, imaj ve tüketime dayalı boş zaman faaliyetleri üzerine kurulan post modern kimlik akışkan, hızlı değişime açık, hareketli, tüketilip tekrar tekrar yeniden üretilen bir yapıya sahiptir. Bu durum da kaçınılmaz olarak kimlikte çoğulculuk ve çeşitliliği getirmektedir. ${ }^{25}$

Sanat ve kimlik kavramı arasında, birbirini etkileyen ve karşılıklı olarak birbirini biçimlendiren bir ilişki vardır. Sanat, kimliğin ifade araçlarından biridir. Özellikle Batılı toplumlarda görsel sanatların etkin bir araç olarak kullanıldığı görülmektedir. Bireysel ve toplumsal olarak iki ayrı süreçte incelenen kimliğin oluşturulması, ifade edilmesi, öğretilmesi ve yaygınlaştırılmasında görsel sanatlar önemli bir rol üstlenmektedir. Sanat tarihine bakıldığında, kimlik ve toplumsal kimlikleri oluşturan

21 "Kimlik", Türk Dil Kurumu, Türkçe Sözlük, s.873.

22 Muhittin Aşkın, "Kimlik ve Giydirilmiş Kimlikler”, Atatürk Üniversitesi Sosyal Bilimler Dergisi, 10/2 (2007), s.213.

23 Sibel Karaduman, “Modernizmden Postmodernizme Kimliğin Yapısal Dönüşümü”, Journal of Yaşar Üniversitesi, 17/5 (2010), s.2886.

24 Bahtinur Möngü, "Postmodernizm ve Postmodern Kimlik Anlayıș”, Atatürk Üniversitesi Sosyal Bilimler Dergisi, 17/2 (2013), s.33.

25 Karaduman, “Modernizmden Postmodernizme”, s.2886. 
inançlar, düşünce yapıları, üretim biçimleri, yaşamı algılama ve yorumlama şekillerinin, sanat eserlerinde nesnelleştirildiği, bu eserler üzerinden tartışılıp yorumlandığ 1 görülür. Kimlik, modern sanatın da temel kavramlarından birini oluşturmaktadır. Modern yaşamda, bireylerin kendilerini ait hissettikleri bir topluluğun ve açık bir kimlik duygusu eksikliğinin söz konusu olduğu vurgulanırken, Herbert Marcuse kapitalizmin üretim biçimlerinin sıradanlaştırdığı modern yaşamın, "tek boyutlu insan kimliği” geliştirdiğini ifade etmektedir. Modern sanatta kimliğin toplumsal-psikolojik boyutlarının öne çıktığı görülmektedir. Öte yandan modern sanatın devamı olarak, 1970’ten sonra üretilen sanat eserlerini kapsayan çağdaş sanat, kimliğin, devlet, toplum, ekonomik sistem ve bütün bunların yarattı̆̆ psikolojik boyutlar üzerinden yeniden oluşumunu ve bu oluşumun sorunlarını irdelemektedir. Tarih öncesi çağlardan beri, bir sanat malzemesi olarak kullanılan insan vücudu, çağdaş sanatta, bireysel kimliklerin bir ifade aracı haline gelmektedir. Çağdaş sanatta, toplumsal yapıların barındırdığı açık üst kimlikler kadar, gizli alt kimlikler de yüzeye çıkmaktadır. ${ }^{26}$

1980'li yıllarda küreselleşmeyle birlikte anılan kimlik sorunu post modern sanatta en çok tartışılan temsil alanını oluşturmaktadır. Küreselleşme ile toplumsal ve kolektif kimlikler parçalanmış, kültürel kodlar silinerek yeni global kültürel kodlar, alt-kimlik, üst-kimlik ve melezleşme kavramları ön plana çıkmıştır. Post modern kimlik daha çok imaj, rol ve tüketim kültürü üzerine kurulu bir kimliğ $i^{27}$ ifade etmektedir.

Dolayısıyla kimlik, çağdaş sanatta yeni alanlarda, yeni formlarda ve farklı bakış açılarıyla ele alınmaktadır. Zira çağdaş sanatçılar doküman niteliğindeki eserleriyle mevcut kavramları yeniden tanımlamakta ve yorumlamaktadırlar. ${ }^{28}$

Nitekim 1980'li yıllarda çeşitli Amerikan müzelerinde ırk, etnik köken, cinsiyet ya da cinsel kimlik açısından "farklı" olanların ifade olanağı bulabileceği sergiler düzenlenmeye başlanması, çok-kültürcü eğilimin sanat ortamındaki başlıca göstergesi olmuştur. Sanat ortamında 1980'li yılların son yarısından başlayarak görülen belirgin dönüşüm, 20. yüzyıl boyunca kendi kendini temsil olanağı bulamamış kesimlerin "kimlik" olgusuna odaklanarak ürettikleri yapıtların Batı sanatının sergilendiği ortamlara girmeye başlaması ile olmuştur. ${ }^{29}$

1990'ların başından bu yana görülen bellek, kimlik, yabancılaşma, yaşam, ölüm, doğum, yok oluş, çok kültürlülük, imge, cinsiyet, feminizm, tarih, mit, öteki gibi sorunsallar bazen metaforik bazen de öznel değerler ışığında sanat nesnesine dönüștürülmüş, bugünün güncel sanatının problematikleriyle paralellik göstermiştir. Kimlik, bellek, yaşam, ölüm, çok kültürlülük, cinsiyet gibi kavramları çağdaş sanatçılar yeni bir sorgu biçimiyle tekrar tekrar yorumlamış; enformasyon, teknoloji ve yeni biçimlerle mevcut kavramları yeniden tanımlamışlardır. ${ }^{30}$

26 Papila, "Kimliğin Anlatım Aracı”, s.176-189.

27 Kafiye Özlem Alp, "Sanatın Temsili ve Postmodern Sanatta Temsil”, ART-E Süleyman Demirel Üniversitesi Güzel Sanatlar Fakültesi Hakemli Dergisi, 12 (2013), s.56.

28 Uçar, "Çağdaş Sanatta Kimlik".

29 Ahu Antmen, 20. Yüzyıl Batı Sanatında Akımlar, İstanbul: Sel Yayıncılık, 2014, s.295.

30 Uçar, "Çağdaş Sanatta Kimlik", s.420. 
Çağımızın kendine özgü, cesur ve en sıra dışı ismi olan Perry, büyük incelikle işlenmiş seramik eserlerinin yanında nakış, fotoğraf, baskı ve heykel gibi geniş çeşitlilikte başka araçlarla çalışmakta ve eserlerinde sıkça kimlik sorununu ele almaktadır. Sanatçının işlerinin pek çoğu otobiyografik unsurlar taşırken, "kimlik", "alter-ego" kavramlarına tarzıyla da gönderme yapmaktadır. Bu durumun çağdaş sanatın vurguladığı ve aktardığ1 çoğulcu görsel imgelerden oluşan kimlik yaklaşımını ${ }^{31}$ yansıttığ1 görülmektedir. Perry, eserlerinde gerçek insan hikayeleri üzerinden milliyetçilik, aile, din, cinsiyet gibi kavramları sorgulatmakta ve bu kavramlara bir meydan okuma sergilemektedir.

Perry’nin, ortak özellikleri kimliğini değiștiren veya kimliği değișen "sıradan insanları" oluşturan 2014 yılına ait 14 eserine bakıldığında, bunlar arasında Müslüman olan bir İngiliz kadın, cinsiyetini değiştiren ve erkek olan bir genç, iki eşcinsel babanın kurduğu bir aile, gözden düşen ve itibarını kaybeden bir politikacı, bir Alzheimer hastası bulunmaktadır. Perry, bu kişilerin her biriyle üç-dört gün geçirerek, onları anlamaya çalışmış ve duygu, düşüncelerini mini bir portreye, bir halıya, bir vazoya, ipek bir eşarba aktarmıştır.

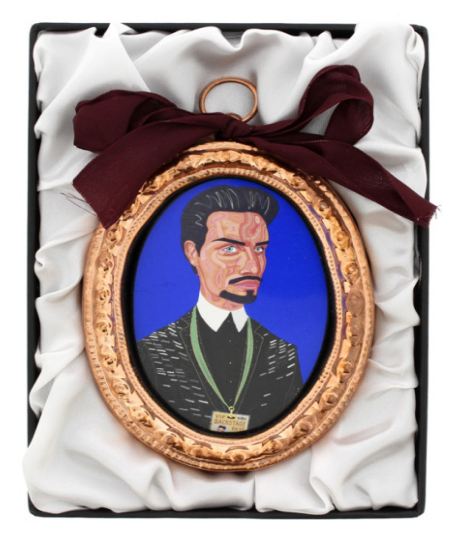

\section{Resim 1. "The Earl of Essex" (Essex Kontu)}

The Earl of Essex (Essex Kontu) ismini taşıyan mini portre, Perry’nin fiziksel özellikleri dikkat çekici, masmavi gözleri, kabarık saçları ve bembeyaz dişleri ile "çıtkırıldım bir asilzade"yi hatırlattığını söylediği Rylan Clark’a aittir. Rylan Clark, havalı bir görünüşe sahip, yirmi altı yaşında ve bir yetenek yarışmasında finale yükselerek çok kısa bir sürede ünlü olmuş, birçok hayranı bulunan televizyon çağının yeni yıldızlarından biridir. Londra’nın kuzeydoğusunda bulunan ve aksanıyla sık sık dalga geçilen Essex bölgesinde doğup büyüyen Rylan Clark’in portresinin altında Perry'nin "yaşadığımız dönemin aristokratları ünlülerdir” açıklaması yer almaktadır. Perry, “21. yüzyıla ait ünlü portrelerinin doğal tuali cep telefonu ekranlarıdır." diyerek, Rylan Clark’ın portresini neden minik yaptığını da açıklamaktadır. ${ }^{32}$

31 Uçar, “Çağdaş Sanatta Kimlik”, s.422.

32 “Grayson Perry Climbing The Populist Mountain Serpentine Review”, Artlyst, son güncelleme 28 Ocak, 2018. http://www.artlyst.com/reviews/grayson-perry-climbing-populist-mountain-serpentine-review-edward-luciesmith. 
Eserlerinde İngiliz kültürünü ve kimliğini de çalışan Perry, halıdan dokuduğu ve bir duvarı tamamen kaplayan bir banknotun üzerine İngiliz kültürünü ve kimliğini nakış nakış işlemiştir. Pop-art’ı çağrıştıran, renkli ve karmakarışık bir eser olarak tanımlanan "Comfort Blanket" (Konforlu Battaniye) isimli bu eser, İngiliz olmanın ne demek olduğu yorumundan ileri gelmektedir. İngiltere banknotlarında fotoğrafı bulunan 88 yaşındaki Kraliçe II. Elizabeth, çay, "fish and chips", İngiliz bayră̆ı, sızlanma, Shakespare, Hint yemekleri, yağmur, David Bowie gibi İngiliz sanatçlar, özgürlük gibi unsurlar İngiliz kültürünün ve kimliğinin yapı taşları olarak bu banknotta yerini almaktadır. Macar bir arkadaşının İngiltere’ye göç eden annesinin, İngiltere'yi sarınabileceği bir güvenlik battaniyesi olarak tanımlaması sebebiyle Perry, eserine bu ismi verdiği ifade etmektedir. ${ }^{33}$

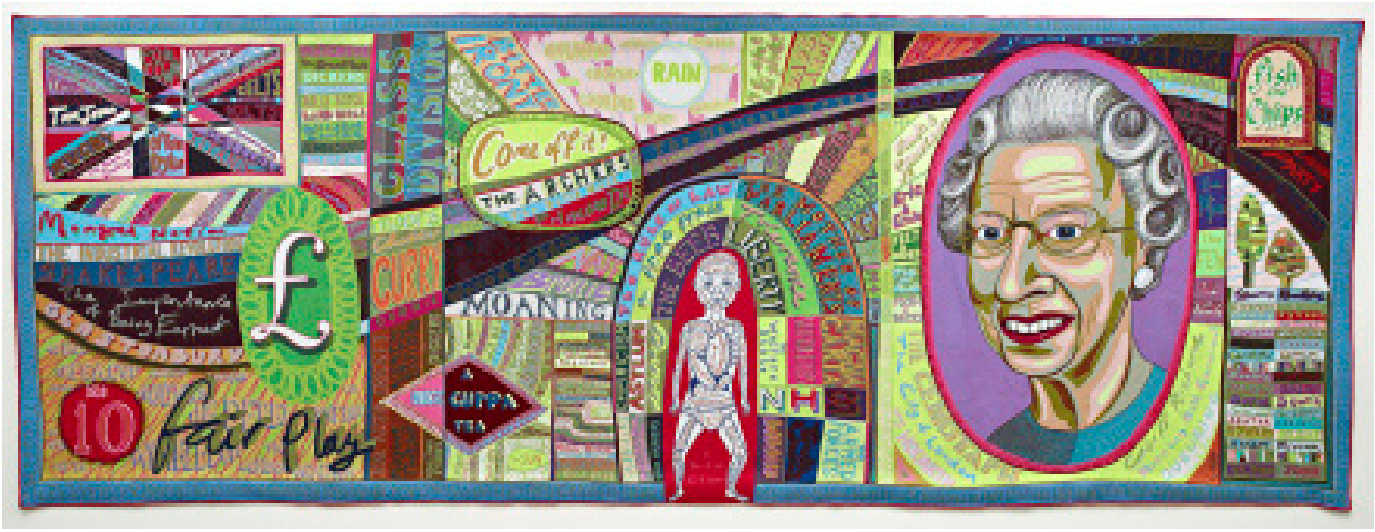

\section{Resim 2. "Comfort Blanket" (Konforlu Battaniye)}

Perry’nin, Küçük Farklılıklar isimli sergisinde yer alan eserlerinde de sınıfa ve kimliğe dair düşüncelerini gösteren çalışmaları görmek mümkündür. Eserlerinde kişinin hangi toplumsal gruba ait olduğunu ve nelere özlem duyduğunu küçük ayrıştırıcı unsurlar üzerinden betimleyen Perry, insanların hayatlarındaki giysi, araba veya hobi tercihleri gibi unsurlar, ayrıntılar, farklılıklar üzerinden kimlik inşaasına vurgu yapmaktadır. Toplumları oluşturan bireyleri, toplum düzeni içinde "ötekileştiren, ayrıştıran, düşmanlaştıran” unsurların sadece etnik, dini, cinsel, politik unsurlar olmadığını, bunların yanı sıra fitness fanatikleri, sigara içmeyenler, şişman insanlar, çocuksuz çiftler gibi örneklerle "küçük farklılıkların" da bireyi ve bazı toplumsal sınıfları ötekileştiren nedenler arasında yer aldığını ifade etmektedir.

Britanya toplumunun farklı sınıfsal katmanlarından ailelerle etnografik araştırma kalibresinde görüşmeler yapan Perry, 1980’ler neo-liberal geçiş öncesi ve sonrasında bu toplumda yaşanan değişime dair deneyimleri gündelik yaşam üzerinden derlemiştir. Derlediklerini ise hayali bir karakter olan Tim Rakewell'in biyografisinden önemli kesitler odağında devasa halılar üzerine işlemiştir. 2x4 metre boyutundaki altı halıdan oluşan ve "Kafeste Kavga Edenlerin Secdesi", "Otoparkta Istırap", "8 Numaralı Cennet Sokağından Kovulma”, "Bakire Anlaşmasının Tebliğii”, "Üst Sınıf

33 “Peki Ama Kim Bu Grayson Perry”, Londra Notları, erişim 01 Şubat, 2018, https://londranotlari.wordpress. com/2015/03/08/peki-ama-kim-bu-grayson-perry. 
Çıkmazda” ve "Ağıt" adlarını taşıyan büyük boy halılar, İngilizlerin zevk ve sınıf düşkünlüklerinin izini sürmekte ve sergilemektedir. Tanınmış isimlerin malikânelerinde yer alan halıların dokunduğu Flanders'da üretilen bu halılar içerik ve renk bakımından oldukça zengin bir yapı sunmaktadır. Eserlerde, Birleşik Krallık’ta yaşamın, iç tasarımdan mutfağa, politik protestodan ünlü dedikodularına kadar her alanında, kendine has yanları ve de tuhaflıkları betimlenmektedir. Perry, kurmaca karakteri Tim Rakewell'in çocukluktan ergenliğe ve orta yaşlarındaki ölümüne kadar anlattığı hayatı üzerinden Birleşik Krallık'taki toplumsal sınıfların öne çıkan özelliklerini ve estetik algılarını ortaya koymaktadır. İngiliz toplumunun işçi sınıfı, orta sınıf ve üst-orta sınıf olmak üzere üç sınıfını, ikişer halıda resmedilmiş ikişer sahne ile ele almaktadır. Böylelikle Perry’nin son iki yüzyıllık dünya tarihinin en tartışmalı kavramlarından biri olan "sınıf" konusunda oldukça özgün bir yaklaşım sergilediği ve İngiltere'deki toplumsal sorunları ele aldığı görülmektedir. ${ }^{34}$

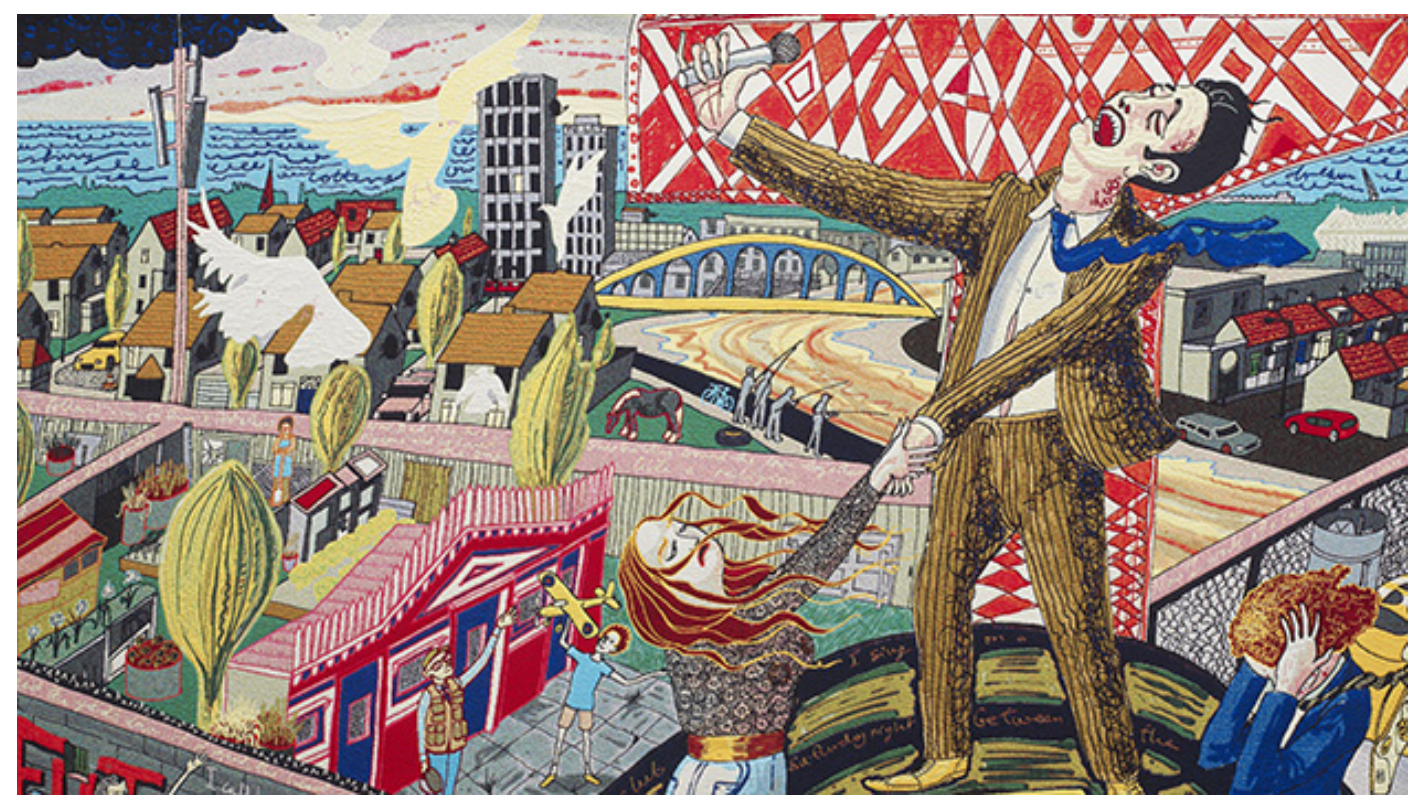

Resim 3. "The Agony in the Car Park" (Otoparkta Istırap)

Miras aldığı serveti verdiği kötü kararlar sonucu yitiren Tim Rakewell'in mütevazı bir ailede doğuşundan gençliğinde büyük bir şöhret oluşuna ve ölümüne kadar süren yolculuğunu, çağdaş Britanya toplumu aracılığıyla anlatarak sınıf sistemine odaklanan Perry'nin, 18. yüzyılda yaşamış İngiliz ressam William Hogarth’ın "Bir Hovardanın Seyri” (A Rake’s Progress -1733) adlı çalışmasından ilham aldığı görülmektedir. Nitekim Perry'nin eserlerinde sanat tarihi imgelerinden, özellikle devlet koleksiyonlarında yer alan erken Rönesans dönemine ait dini eserlerden esinlendiğ $i$ izlenmektedir. ${ }^{35}$ Ancak esas olarak, Perry’nin eserlerindeki sahneler, İngiltere'deki seyahatlerinde karşılaştığı gerçek kişiler, yerler, nesneler üzerine kuruludur ve bireysel,

34 Caroline Douglas, Suzanne Moore, Grayson Perry: The Vanity of Small Differences, London: Hayward Gallery Publishing, 2013; “Grayson Perry Türkiye'de”, British Council, erişim 25 Ocak, 2018, https://www.britishcouncil. org.tr/graysonperry/turkey.

35 "Grayson Perry ve Küçük Farklılıklar", Salom, son güncelleme 28 Ocak, 2018, http://www.salom.com.tr/ haber-95800-grayson_perry_ve_kucuk_farkliliklar.html. 
toplumsal sorunlara değinmektedir. Perry, İngiltere’nin değişik bölgelerini gezerek, farklı sosyal sınıfların, bireylerin zevklerini, yaşantılarını araştırmakta ve gözlemlerini eserlerine aktarmaktadır. Orta sınıfa özgü sıkıntıları, mirasyedilerin züppeliğini, sanayinin, işsizliğin toplumda ve bireyde yarattığı mağduriyeti çarpıcı şekilde işlemekte ve din, sosyal sınıf, statü ve zevkler gibi insanların kimliğini oluşturan ve onları farklılaştıran kavramları gerek hayal dünyasının gerekse eserlerinin merkezinde tutmaktadır.

\section{Sonuç}

Görsel sanatlar, kimliğin oluşturulması, ifade edilmesi, öğretilmesi ve yaygınlaştırılmasında etkin bir araç olarak önemli bir görev üstlenmektedir. Bu kapsamda çağdaş sanatın ve çağdaş sanatçıların da kimlik kavramını çok boyutlu olarak ele aldığı, görülen, gösterilen, açı üst kimliklerle beraber farklı cinsel kimlikler ve alt kimlik gibi konuları da kapsadığı görülmektedir.

Farklı disiplinleri, çeşitli kültür ve değerleri, sıra dışı materyalleri ve görsel imgeleri tecrübelerinden, tarihten, gözlemlerinden ve çevreden referans alarak aynı potada eriten Grayson Perry, bu tarzı ve konuları ele alışı ile günümüz çağdaş sanat temsilcileri arasında hızla kendini göstermektedir. Grayson Perry’nin çalışmalarında ağırlık verdiği kimlik ve cinsiyet temaları da 20.yüzyıl çağdaş sanat çalışmalarının temel temalarını oluşturmaktadır. Bireysel kimlik ve toplumsal kimlik temaları, çağdaş sanat ve çağdaş sanatçıların eserleri içerisinde önemli bir yer bulmaktadır. Toplumsal kimliğin bireyin içinde yaşadığı toplum ile etkileşime girerek sonradan geliştirilebilmesi kendini Perry'nin eserlerinde de göstermektedir.

Çağdaş sanatçılar ortaya koydukları eserlerinde geçmişle kıyasladığımızda yeni malzeme ve teknik olanaklarla farklılık sergilemektedirler. Toplumsal, kültürel, öznel, hayata dair kavramların ve değerlerin yeniden sorgulandığ ry’nin de gerek kompozisyonları gerekse kullandığı malzeme çeşitliliği, teknikleri ile fark yarattı̆̆g görülmektedir.

Eserlerinde akrilik, yün, pamuklu halı, sırlı seramik, ipek halı, polyester ve yedirme baskı yöntemini kullanan Perry, eserleri ve hissettirdikleriyle "çağdaş hayatın bir vakanüvisi” olarak tanımlanmaktadır. Cinselliğin bastırılmasından ön yargılara, dini konulardan davranış kalıplarına kadar farklı konuları ele aldığı eserlerinde, modern dertler, siyaset, sınıf ve kimlik konularını çarpıcı bir şekilde yorumlamaktadır.

Çok kültürlü ve çok katmanlı bir yapıyı yansıtan, eserlerinde esas olarak Britanya'yı merkeze alan Perry, Britanya’nın meselelerine odaklanmakta, sosyal sınıflar ve kimlik gibi evrensel konuları da can alıcı şekilde ve zarafetle ele almaktadır. Gerçek hayattan karakterleri, olayları ve nesneleri eserlerine taşıyarak sanatını farklı kılan sanatçı, çağdaş sanatı da ironik bir şekilde eleştirmektedir.

Gündelik olana, insanların yaşam biçimlerine olan derin ilgisi ile Perry eserlerinde bir yaşam döngüsü ve sosyolojik bir panorama çıartmaktadır. Bunun en güzel örneği olarak altı halıdan oluşan eser serisini vermek mümkündür. Zira bu eser serisinde 
bir ailenin sınıf atlama serüveni ve kurmaca karakteri Tim Rakewell üzerinden İngiltere'deki sosyal sınıfları, bireysel kimlik ve toplumsal kimlik konularını işleyerek hem yaşam döngüsü hem de sosyolojik bir analiz ortaya koymaktadır.

Etnik, dini, cinsel, politik unsurların yanı sıra bireylerin sahip oldukları özellikler, doğumdan ölüme kadar kişinin yaşadığı aile ve toplumla etkileşimi, kullandığı eşyalar, satın aldığı markalar, özlem duydukları şeyler gibi farklılıkların bireyi nasıl etkilediği, nasıl değiştirdiği yönünde bir bakış açısıyla kimlik konusunu yeni bir ele alış biçimi ortaya koymaktadır. Nitekim zaman zaman travesti kılığına bürünen Perry’nin dişil yansıması olan ve eserlerinde karşımıza çıkan Claire karakteri, oyuncak ayısı Alan Measels, Essex'li Rylan Clark, yoksul bir ailede doğup gençliğinde kazandığ 1 şöhret ve zenginlik ile "sonradan görme" tavırlar sergileyen Tim Rakewell bu bakış açısına örnek verilebilecek temsilleri oluşturmaktadır. Dolayısıyla bu karakterler ile Perry, yaşamı, inancı, modern hayatı, gelenekselliği, sosyal sınıfları ve kimliğin oluşumunu sorgulamaktadır.

Perry, çağdaş sanat anlatısında yer verildiği şekilde, öznel ve yerel değerleri harmanlayarak, kendi kimlik süzgecinden geçirmekte, bireysel ve toplumsal kimliği, entelektüel ve estetik bir diyalektik kurgulayarak eserlerine aktarmaktadır.

\section{Kaynakça}

Alp, Kafiye Özlem. "Sanatın Temsili ve Postmodern Sanatta Temsil". ART-E Süleyman Demirel Üniversitesi Güzel Sanatlar Fakültesi Hakemli Dergisi. 12 (2013): 40-61.

Antmen, Ahu. 20. Yüzyıl Batı Sanatında Akımlar. İstanbul: Sel Yayıncılık, 2014.

Artlyst. "Grayson Perry Climbing The Populist Mountain Serpentine Review". Son güncelleme 28 Ocak, 2018. http://www.artlyst.com/reviews/grayson-perryclimbing-populist-mountain-serpentine-review-edward-lucie-smith.

Artun, Ali ve Nursu Örge. Çağdaş Sanat Nedir?. İstanbul: İletişim Yayınları, 2014.

Aşkın, Muhittin. "Kimlik ve Giydirilmiş Kimlikler". Atatürk Üniversitesi Sosyal Bilimler Dergisi. 10/2 (2007): 213-220.

Bayrak, Bengisu. "Çağdaş Sanat Pazarında Bir Marka Olmak: Bir Vaka İncelemesi Olarak Damien Hirst”. Nevşehir Üniversitesi Sosyal Bilimler Dergisi. 2/1 (2012): 240-271.

British Council. "Grayson Perry Türkiyede". Erişim 25 Ocak, 2018. http://www. britishcouncil.org.tr/graysonperry/about.

Çadırc1, Orçun. "Çağdaş Sanat Sürecinde Resimsel Bir Dil Olarak Neo-Geo". Gazi Üniversitesi Güzel Sanatlar Fakültesi Sanat ve Tasarmm Dergisi. 5(2010): 53-60.

Douglas, Caroline, Suzanne Moore. Grayson Perry: The Vanity Of Small Differences. London: Hayward Gallery Publishing, 2013.

Fredric, Jameson, Jean-François Lyotard ve Jürgen Habermas. Postmodernizm. Haz., Necmi Zeka. Çev., Gülengül Naliş, Dumrul Sabuncuoğlu, Deniz Erksan. İstanbul: Kıyı Yayınları, 1994.

Jones, Wendy. Grayson Perry: Portrait of an Artists As A Young Girl. UK: Vintage Books, 2007. 
Karaduman, Sibel. "Modernizmden Postmodernizme Kimliğin Yapısal Dönüşümü”. Journal of Yaşar Üniversitesi. 17/5 (2010): 2886-2899.

Kikasworld. "Grayson Perry Üzerine”. Erişim 28 Ocak, 2018. https://kikasworld. com/2015/06/18/grayson-perry-uzerine.

Klein, Jacky. Grayson Perry. 2nd Edition, London: Thames \& Hudson, , 2009.

Londra Notları. "Peki Ama Kim Bu Grayson Perry”. Erişim 01 Şubat, 2018. https:// londranotlari.wordpress.com/2015/03/08/peki-ama-kim-bu-grayson-perry.

Mimarizm. "Grayson Perry’den Küçük Farklllıklar". Erişim 27 Kasım, 2017. http://www.mimarizm.com/etkinlikler/sergiler/grayson-perry-den-kucukfarkliliklar_121380.

Möngü, Bahtinur. "Postmodernizm ve Postmodern Kimlik Anlayısıı". Atatürk Üniversitesi Sosyal Bilimler Dergisi. 17/2 (2013): 27-36.

New Statesman. "Grayson Perry: The Rise and fall of Default Man". Erişim 1 Şubat, 2018. https://www.newstatesman.com/culture/2014/10/grayson-perry-riseand-fall-default-man.

Papila, Aytül. "Kimliğin Anlatım Aracı Olarak Sanat". Beykent Üniversitesi Sosyal Bilimler Dergisi. 1 (2007): 176-190.

Perry, Grayson. Playing to the Gallery. Penguin Books Ltd., 2014.

Rajchman, John. "Çağdaş : Yeni Bir Fikir mi?”. Çağdaş Sanat Nedir?. Ed., Ali Artun, Nursu Örge. İstanbul: İletişim Yayınları, 2014, 19-40.

Salom. "Grayson Perry ve Küçük Farklllıklar". Erişim 28 Ocak, 2018. http://www. salom.com.tr/haber-95800grayson_perry_ve_kucuk_farkliliklar.html.

Türk Dil Kurumu. Türkçe Sözlük. Ankara, 2006.

Uçar, Alpaslan. "Çağdaş Sanatta Kimlik Açılımı ve Yeni Önermeler". Ege Eğitim Dergisi. 15/2 (2014): 416-427.

Whitham, Graham ve Grant Pooke. Çağdaş Sanatı Anlamak. Çev., Tufan Göbekçin. İstanbul: Optimist Yayınları. 2010.

Yaman, İsmail Şamil, Tahir Ekim, Serpil Sungur ve Ceyhan Özer. Çağdaş Dünya Sanatı. Ankara: Saray Matbaacilık, 2013.

Yılmaz, Mehmet. Modernizmden Postmodernizme Sanat. Ankara: Ütopya Yayınları, 2006. 
İNSAN\&İNSAN, Y11/Year 6, Sayı/Issue 19, Kış/Winter 2019, 63-77

DOI: https://doi.org/10.29224/insanveinsan.407617

\title{
Contemporary Art and Identity: A Review from Grayson Perry Artworks
}

\author{
ÇIĞDEM SAÇ KAVRAYAN
}

Abstract: From the 1960s to the present, contemporary art forms a movement in which artists are completely differentiated in terms of production methods. Contemporary art deals with concepts such as feminism, globalization, environment, technology, identity and class. It is seen that contemporary artists differ with interdisciplinary studies, various materials and different techniques. Contemporary artists also discuss different sexual identities and subidentities within their wide range of interests. Grayson Perry is one of Britain's most renowned contemporary artists. It is considered to be one of the most extraordinary and iconic names of contemporary art. Grayson Perry discusses class differences in society, modern problems and issues of identity. Grayson Perry, who works in ceramics, printing and sculpture, uses various materials such as silk, cotton fabric, rice, photography in his compositions. This study examines Grayson Perry's concept of identity in his compositions.

Keywords: Art, Contemporary art, Grayson Perry, Identity, Class. 